\title{
Phase Behavior of Hydrocarbon-like Primary Organic Aerosol and Secondary Organic Aerosol Proxies Based on Their Elemental Oxygen-to-Carbon Ratio
}

\author{
Fabian Mahrt, Elli Newman, Yuanzhou Huang, Markus Ammann, and Allan K. Bertram*
}

Cite This: Environ. Sci. Technol. 2021, 55, 12202-12214

Read Online

ACCESS

山 Metrics \& More

回国 Article Recommendations

Supporting Information

ABSTRACT: A large fraction of atmospheric aerosols can be characterized as primary organic aerosol (POA) and secondary organic aerosol (SOA). Knowledge of the phase behavior, that is, the number and type of phases within internal POA + SOA mixtures, is crucial to predict their effect on climate and air quality. For example, if POA and SOA form a single phase, POA will enhance the formation of SOA by providing organic mass to absorb SOA precursors. Using microscopy, we studied the phase behavior of mixtures of SOA proxies and hydrocarbon-like POA proxies at relative humidity $(\mathrm{RH})$ values of $90 \%, 45 \%$, and below $5 \%$. Internal mixtures of POA and SOA almost always formed two phases if the elemental oxygen-to-carbon ratio $(\mathrm{O} / \mathrm{C})$ of the POA was less than 0.11 , which encompasses a large fraction of

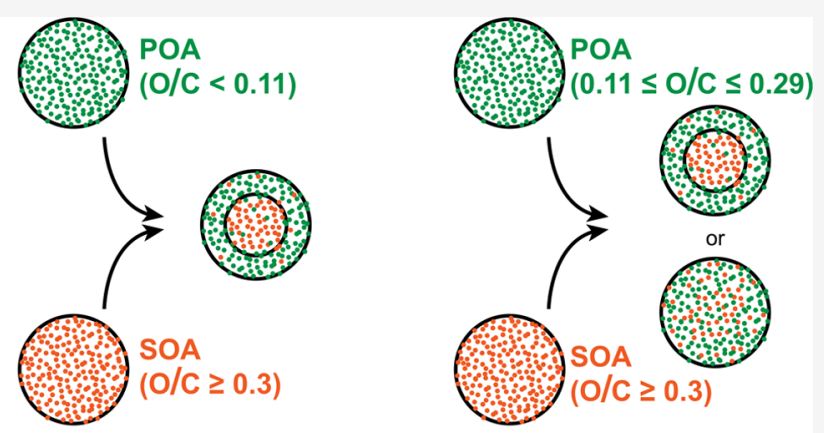
atmospheric hydrocarbon-like POA from fossil fuel combustion. SOA proxies mixed with POA proxies having $0.11 \leq \mathrm{O} / \mathrm{C} \leq$ 0.29 mostly resulted in particles with one liquid phase. However, two liquid phases were also observed, depending on the type of SOA and POA surrogates, and an increase in phase-separated particles was observed when increasing the $\mathrm{RH}$ in this $\mathrm{O} / \mathrm{C}$ range. The results have implications for predicting atmospheric SOA formation and policy strategies to reduce SOA in urban environments.

KEYWORDS: atmospheric aerosol particles, air pollution, phase behavior, organic aerosol particles, secondary organic aerosol, primary organic aerosol, microscopy

\section{INTRODUCTION}

Organic aerosol particles are abundant in the atmosphere, comprising $\sim 10-90 \%$ of the mass fraction of submicron particulate matter (PM), depending on the location and the season. ${ }^{1-6}$ Organic aerosols are important for many environmental processes: they influence atmospheric chemistry, ${ }^{7-9}$ contribute to air pollution, ${ }^{10,11}$ and negatively affect human health. ${ }^{12-16}$ They also exert an impact on climate directly by absorbing and scattering solar radiation and indirectly by influencing cloud microphysical and radiative properties when acting as cloud nuclei. ${ }^{5,17,18}$

Atmospheric organic aerosols comprise a wide range of compounds with different volatilities, molecular weights, polarities, oxidation states, and functional groups. ${ }^{2,19-22}$ In general, they can be broadly classified as primary organic aerosol (POA) and secondary organic aerosol (SOA) particles. POA denotes organic aerosols that are directly emitted into the atmosphere as particles. Emission sources of POA include automobile exhaust, cooking operations, and biomass burning. ${ }^{5}$ SOA, on the other hand, is formed within the atmosphere from the oxidation of organic precursor gases, including volatile organic compounds (VOCs), intermediate-volatility organic compounds, and semivolatile organic compounds, leading to products with lower volatilities that can partition to the particle phase. $^{23-26}$ At the same time, a variety of condensed phase processes can also contribute to SOA formation. ${ }^{27,28}$

Previous measurements have detected hydrocarbon-like organic aerosol (HOA) as a main type of POA in urban environments. ${ }^{1,3} \mathrm{HOA}$ is thought to originate mainly from fossil fuel combustion, for example, motor vehicle exhaust in urban environments. ${ }^{29-32}$ Unburnt engine lubricating oil, with an elemental oxygen-to-carbon ratio $(\mathrm{O} / \mathrm{C})$ of around $0.02,{ }^{33}$ usually makes up a large fraction of motor vehicle exhaust. ${ }^{31,34-37}$ Nonetheless, the average $\mathrm{O} / \mathrm{C}$ of atmospheric HOA has been reported to typically range from approximately 0.02 to $0.26,^{38}$ depending on engine combustion conditions, ${ }^{39}$ the overall mass concentration of $\mathrm{HOA}^{31}$ the degree of atmospheric oxidation of engine lubricating oil particles, ${ }^{40}$ and

Received: April 24, 2021

Revised: August 5, 2021

Accepted: August 9, 2021

Published: September 2, 2021

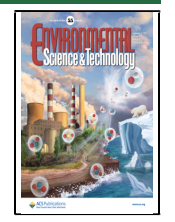




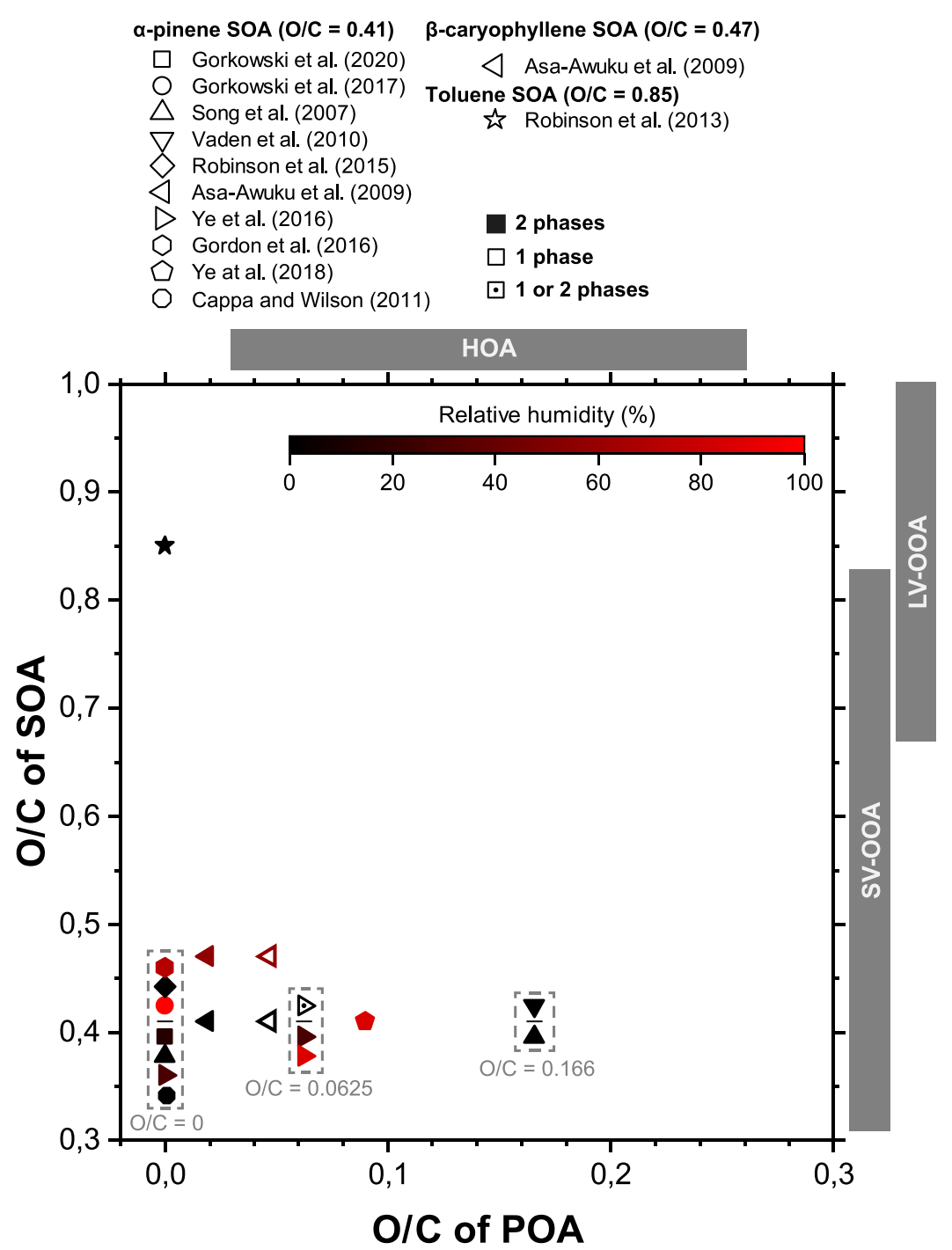

Figure 1. Summary of previous experiments that investigated the phase behavior of internal mixtures of POA and SOA proxies as a function of their $\mathrm{O} / \mathrm{C}$ ratios. The $\mathrm{O} / \mathrm{C}$ of the SOA types is indicated in the legend and is based on Canagaratna et al. ${ }^{38}$ The gray, vertical bars indicate the typical ranges for SV-OOA and LV-OOA. Previous experiments included here were limited to POA with O/C below 0.26, relevant for hydrocarbon-like POA (HOA) observed in the atmosphere, as indicated by the gray, horizontal bar, and based on the classification of Canagaratna et al. ${ }^{38}$ Small horizontal, black lines indicate locations where multiple experiments were performed for the same O/C ratios of the POA and SOA. The corresponding experiments are vertically offset to avoid overlapping and are surrounded by dashed boxes for the ease of identification. The RH of each experiment is indicated by the colormap, and the corresponding study is given in the legend. Open (filled) symbols denote experiments where one (two) phases were reported or inferred. The open symbol with a dot inside denotes an experiment where the number of phases could not be fully constrained, as detailed in the text. See also Table 1 for details.

internal mixing of engine lubricating oil particles with oxidized organic compounds formed during incomplete combustion. $^{31,41}$

Based on aerosol mass spectrometry studies, SOA is often subdivided into semi-volatile-oxygenated organic aerosol (SVOOA) and low-volatility oxygenated organic aerosol (LVOOA). ${ }^{1,38}$ Previous field measurements have shown that the average $\mathrm{O} / \mathrm{C}$ ratios of SV-OOA and $\mathrm{LV}-\mathrm{OOA}$ range from approximately 0.32 to $0.83^{38}$ and 0.68 to $1.32,{ }^{38}$ respectively, representing fresh and more oxidized, atmospherically aged SOA.

In and downwind of urban environments, air masses can contain both POA and SOA. ${ }^{1,3,30,42}$ Coagulation, gas-particle partitioning, and multiphase chemical reactions can result in internally mixed aerosol particles containing both POA and SOA material. ${ }^{30,43-47}$ Timescales for POA and SOA to become internally mixed within individual aerosol particles can range from minutes ${ }^{48}$ to hours, ${ }^{49}$ depending on the mixing process and the ambient conditions.

Information on the phase behavior, that is, the number and types of phases in internal mixtures of POA and SOA, is needed to predict their role in air quality and the climate. ${ }^{50}$ For example, knowledge on the phase behavior of POA and SOA mixtures is needed to correctly predict the mass of SOA that will form in the atmosphere. If internally mixed POA + SOA aerosols form single-phase particles, the presence of POA will enhance the formation of the SOA mass in the atmosphere: in a single-phase particle, the activity of the POA and SOA materials is lower compared to that in separate POA and SOA phases. ${ }^{51}$ Owing to the decrease in activity, the equilibrium partial pressure is reduced, shifting the thermodynamic equilibrium between the gas and the particle phase to the 
Table 1. Summary of Previous Studies That Investigated the Phase Behavior of Mixtures of POA and SOA Proxies ${ }^{a}$

\begin{tabular}{|c|c|c|c|c|c|}
\hline POA proxy $(\mathrm{O} / \mathrm{C})$ & SOA proxy $(\mathrm{O} / \mathrm{C})$ & RH (\%) & type of observation & $\begin{array}{l}\text { number of phases inferred/ } \\
\text { reported }\end{array}$ & reference \\
\hline squalane $(0)$ & $\alpha$-pinene ozonolysis $\left(0.41^{b}\right)$ & $12^{e}$ & number of phases & +5 & $\begin{array}{l}\text { Gorkowski et al. } \\
(2020)^{69}\end{array}$ \\
\hline squalane $(0)$ & $\alpha$-pinene ozonolysis $\left(0.41^{b}\right)$ & $<20^{c}$ & miscibility & 2 & Ye et al. $(2016)^{72}$ \\
\hline squalane $(0)$ & $\alpha$-pinene ozonolysis $\left(0.41^{b}\right)$ & $55-56^{c}$ & miscibility & 2 & Gordon et al. $(2016)^{74}$ \\
\hline squalane $(0)$ & $\alpha$-pinene ozonolysis $\left(0.41^{b}\right)$ & $<5^{d}$ & miscibility & 2 & $\begin{array}{l}\text { Robinson et al. } \\
(2015)^{77}\end{array}$ \\
\hline squalane $(0)$ & $\alpha$-pinene ozonolysis $\left(0.41^{b}\right)$ & $\sim 80^{e}$ & number of phases & 2 & $\begin{array}{l}\text { Gorkowski et al. } \\
(2017)^{79}\end{array}$ \\
\hline squalane $(0)$ & $\begin{array}{l}\text { toluene SOA from photo- } \\
\text { oxidation }\left(0.85^{b}\right)\end{array}$ & $5^{d}$ & miscibility & 2 & $\begin{array}{l}\text { Robinson et al. } \\
(2013)^{76}\end{array}$ \\
\hline lubricating oil $10 \mathrm{~W}-30(\sim 0)$ & $\alpha$-pinene ozonolysis $\left(0.41^{b}\right)$ & $\mathrm{N} / \mathrm{A}$ & $\begin{array}{l}\text { miscibility and number of } \\
\text { phases }\end{array}$ & 2 & $\begin{array}{l}\text { Cappa and Wilson } \\
(2011)^{78}\end{array}$ \\
\hline $\begin{array}{l}\text { lubricating oil SAE } 15 \mathrm{~W}-40 \\
(\sim 0)\end{array}$ & $\alpha$-pinene ozonolysis $\left(0.41^{b}\right)$ & $2^{d}$ & miscibility & 2 & Song et al. $(2007)^{73}$ \\
\hline $\begin{array}{l}\text { motor oil + diesel fuel POA } \\
(0.019)\end{array}$ & $\alpha$-pinene ozonolysis $\left(0.41^{b}\right)$ & $5^{d}$ & miscibility & 2 & $\begin{array}{l}\text { Asa-Awuku et al. } \\
(2009)^{33}\end{array}$ \\
\hline $\begin{array}{l}\text { motor oil }+ \text { diesel fuel POA } \\
(0.019)\end{array}$ & $\begin{array}{l}\beta \text {-caryophyllene ozonolysis } \\
\left(0.47^{\circ}\right)\end{array}$ & $5^{d}$ & miscibility & 2 & $\begin{array}{l}\text { Asa-Awuku et al. } \\
(2009)^{33}\end{array}$ \\
\hline $\begin{array}{l}\text { diesel engine exhaust POA } \\
(0.047)\end{array}$ & $\alpha$-pinene ozonolysis $\left(0.41^{b}\right)$ & $5^{d}$ & miscibility & 1 & $\begin{array}{l}\text { Asa-Awuku et al. } \\
(2009)^{33}\end{array}$ \\
\hline $\begin{array}{l}\text { diesel engine exhaust POA } \\
(0.047)\end{array}$ & $\begin{array}{l}\beta \text {-caryophyllene ozonolysis } \\
\left(0.47^{b}\right)\end{array}$ & $5^{d}$ & miscibility & 1 & $\begin{array}{l}\text { Asa-Awuku et al. } \\
(2009)^{33}\end{array}$ \\
\hline hexadecanol ${ }^{f}(0.0625)$ & $\alpha$-pinene ozonolysis $\left(0.41^{b}\right)$ & $<20^{c}$ & miscibility & 2 & Ye et al. $(2016)^{72}$ \\
\hline hexadecanol $f^{f}(0.0625)$ & $\alpha$-pinene ozonolysis $\left(0.41^{b}\right)$ & $2-5^{d}$ & miscibility & 1 or 2 & Ye et al. $(2016)^{72}$ \\
\hline hexadecanol ${ }^{f}(0.0625)$ & $\alpha$-pinene ozonolysis $\left(0.41^{b}\right)$ & $55-60^{c}$ & miscibility & 2 & Ye et al. $(2016)^{72}$ \\
\hline $\begin{array}{l}\text { diesel engine exhaust POA } \\
\quad(0.09)\end{array}$ & $\alpha$-pinene ozonolysis $\left(0.41^{b}\right)$ & $40-60^{d}$ & miscibility & 2 & Ye et al. $(2018)^{70}$ \\
\hline dioctyl phthalate $(0.166)$ & $\alpha$-pinene ozonolysis $\left(0.41^{b}\right)$ & $2^{d}$ & miscibility & 2 & Song et al. $(2007)^{73}$ \\
\hline dioctyl phthalate $(0.166)$ & $\alpha$-pinene ozonolysis $\left(0.41^{b}\right)$ & $5^{d}$ & $\begin{array}{l}\text { miscibility and number of } \\
\text { phases }\end{array}$ & 2 & Vaden et al. $(2010)^{75}$ \\
\hline
\end{tabular}

${ }^{a}$ Previous studies included here were limited to POA with O/C values below 0.29 , relevant for HOA observed in the atmosphere based on the classification of Canagaratna et al. ${ }^{38}$ Indicated are the POA and SOA species, the $\mathrm{RH}$ at which the experiment was performed, type of observations, and the number of phases inferred or reported. Experiments are tabulated for increasing $\mathrm{O} / \mathrm{C}$ of the POA component. ${ }^{b}$ Based on Canagaratna et al. ${ }^{38}{ }^{c}$ Flow tube experiment. ${ }^{d}$ Chamber experiment. ${ }^{e}$ Aerosol optical tweezer. ${ }^{f}$ Melting temperature around $50{ }^{\circ} \mathrm{C}$.

condensed phase, ultimately allowing for more gaseous SOA precursors to be taken up into the particle phase. In contrast, if POA and SOA form two phases when internally mixed, the presence of POA will have a smaller, if any, effect on the formation of SOA mass, with implications for climate predictions, air quality, and associated strategies being considered to reduce SOA mass in urban environments. ${ }^{52}$

The phase behavior of POA and SOA also has important implications for multiphase and heterogeneous chemistry, with implications for the aerosol chemical composition and mass in the atmosphere. ${ }^{7,8,53-57}$ In addition, the phase behavior of POA and SOA can influence the time it takes for a particle to reach equilibrium with the surrounding water and organic vapors. $^{58}$ In a two-phase particle with a core-shell morphology, the inner particle phase is shielded from the surrounding gas phase by the outer phase (shell). In such particles, the diffusion through the outer phase can limit the rate of gas uptake by providing a barrier (i.e., resistor) for mass transfer. Lastly, the formation of multiple phases in internally mixed aerosol particles at high relative humidity $(\mathrm{RH})$ values can impact their ability to act as cloud condensation nuclei. ${ }^{59-64}$

Traditionally, researchers have often assumed that POA and SOA form a single phase when predicting the impact of POA and SOA on air quality and climate using chemical transport models. ${ }^{50,65-67}$ Nevertheless, recent laboratory studies suggest that POA + SOA mixtures can form two phases under some conditions. In Figure 1 and Table 1, we summarize the results of laboratory studies that have measured or inferred the phase behavior of POA + SOA particles or proxies thereof as a function of the $\mathrm{RH}$. The results are shown as a function of the $\mathrm{O} / \mathrm{C}$ ratio of the POA and SOA material because the $\mathrm{O} / \mathrm{C}$ ratio is expected to be closely related to an organic molecule's polarity and hydrophilicity, which are important parameters that influence particle properties such as the phase behavior. ${ }^{68-71}$ In addition, the $\mathrm{O} / \mathrm{C}$ ratio has the practical advantage that it can be readily measured for atmospheric POA and SOA. The data in Figure 1 are constrained to experiments that used POA with $\mathrm{O} / \mathrm{C} \leq 0.26$, that is, POA that is relevant for atmospheric $\mathrm{HOA}^{38}$ In some of these experiments, the phase behavior was inferred by determining the enhancement of SOA particulate mass production in an environmental chamber in the presence of POA seeds..$^{70,72-74}$ In other experiments, the phase behavior was determined by observing the evolution from an initially bi-modal particle (mass) size distribution to a unimodal distribution in a particle population consisting of SOA and POA. ${ }^{33}$ The phase behavior has also been investigated using mass spectrometry ${ }^{75-78}$ as well as optical tweezers, ${ }^{69,79}$ where the number of phases of proxies of POA and SOA was directly observed.

While the previous studies summarized in Figure 1 and Table 1 have provided invaluable information on the phase behavior of internal mixtures of POA and SOA materials, most of these studies have been limited to a handful of POA proxies and SOA types and hence have only covered a limited range of $\mathrm{O} / \mathrm{C}$ ratios. For example, these previous studies have used 
either a POA proxy with a low $\mathrm{O} / \mathrm{C}(\leq 0.09)$ or a POA proxy consisting of dioctyl phthalate $(\mathrm{O} / \mathrm{C}$ of 0.166 ; see Figure 1 and Table 1 for details). In addition, in almost all the cases, the SOA material was derived from $\alpha$-pinene oxidation or $\beta$ caryophyllene oxidation, which have been observed to have average $\mathrm{O} / \mathrm{C}$ ratios of approximately 0.4 and 0.5 , respectively. ${ }^{38}$ On the other hand, the $\mathrm{O} / \mathrm{C}$ ratios of atmospheric hydrocarbon-like POA and SOA typically range between 0.02 and $0.26^{38}$ and between 0.32 and $1.32,{ }^{38}$ respectively. Moreover, the previous experiments summarized in Figure 1 and Table 1 are mostly limited to $\mathrm{RH}$ with respect to water below approximately $20 \%$. On the other hand, the $\mathrm{RH}$ in the atmosphere is most often between 20 and $100 \%,{ }^{80}$ and the gasparticle partitioning of semi volatile species and the phase behavior of POA + SOA mixtures may vary with $\mathrm{RH}^{69,81-85}$ Due to the limited $\mathrm{RH}$ range and limited types of POA and SOA proxies used in the previous studies, considerable uncertainty still exists regarding the phase behavior of atmospheric POA + SOA particles.

In the following, we directly observed the phase behavior of particles containing POA and SOA proxies at $\mathrm{RH}$ levels of $90 \%, 45 \%$, and below 5\%, using optical and fluorescence microscopy. We used commercially available organic species as POA and SOA surrogates, as this allowed us to systematically investigate the POA + SOA phase behavior as a function of their O/C ratios. For POA, we used 13 different types of proxies with average $\mathrm{O} / \mathrm{C}$ ranging from 0 to 0.29 , covering the average $\mathrm{O} / \mathrm{C}$ range relevant for HOA in the atmosphere based on Canagaratna et al. ${ }^{38}$ The phase behavior was investigated by mixing each POA proxy individually with one out of 21 different SOA proxies with average $\mathrm{O} / \mathrm{C}$ values ranging from 0.3 to 1.0, largely covering the range of both SV-OOA and LVOOA in the atmosphere based on Canagaratna et al. ${ }^{38}$

\section{EXPERIMENTAL SECTION}

POA Proxies. For both the POA and SOA materials, organic proxies were selected to have low saturation vapor pressure and to minimize evaporative loss during our experiments and preference was given to organics that are liquid at room temperature, to minimize crystallization. The POA proxies investigated are listed in Table S1 (see the Supporting Information). Commercially available organic species were purchased from Sigma-Aldrich and Alfa Aesar and their $\mathrm{O} / \mathrm{C}$ was calculated from their molecular formula. All the chemicals had purities $\geq 98 \%$ and were used as received, with the exception of dodecyl aldehyde, which was obtained at a purity of $\geq 92 \%$. Engine lubricating oil (Pennzoil, 5W30) and jojoba oil (Cliganic) were also used as POA proxies, and their $\mathrm{O} / \mathrm{C}$ ratios were measured using an elemental analyzer (Thermo Fisher Scientific, model: Thermo Flash 2000). While engine lubricating oil is mostly composed of cyclic and branched hydrocarbons, ${ }^{34,86}$ jojoba oil is mostly composed of high-molecular-weight monoesters of straight chain fatty acids and alcohols. ${ }^{87}$ All the POA proxies had $\mathrm{O} / \mathrm{C}$ values between 0 and 0.29 (Table S1), similar to atmospheric HOA. ${ }^{38}$ To mimic the most hydrophobic HOA at the lower end of this $\mathrm{O} / \mathrm{C}$ range, we used squalane (branched hydrocarbon) and engine lubricating oil (cyclic and branched hydrocarbons) as proxies. Squalane was chosen because it has been used previously as a proxy of HOA (see Table 1). Engine lubricating oil was chosen because it has been shown to be a significant component of HOA in urban environments. ${ }^{32,34,35}$ To mimic atmospheric aging and the more oxidized $\mathrm{HOA}^{88}$ which can be formed in the atmosphere by the oxidation of the more hydrophobic HOA such as lubricating oil, we used commercially available, partially oxidized hydrocarbons with large molecular weights $\left(\geq 130 \mathrm{~g} \mathrm{~mol}^{-1}\right)$. Functional groups in the partially oxidized hydrocarbons were carboxylic acids, esters, aldehydes, aromatics, and alcohols. ${ }^{23,89-93}$ All these functional groups have been identified in atmospheric organic aerosols. $^{23,89-93}$ Some of the POA proxies (e.g., decanoic acid and nonanoic acid) have been identified in atmospheric organic PM. ${ }^{92}$

SOA Proxies. The SOA proxies investigated are listed in Tables S2. Commercially available organic species were purchased from Sigma-Aldrich and Alfa Aesar, and their $\mathrm{O} / \mathrm{C}$ was calculated from their molecular formula. All the chemicals had purities $\geq 98 \%$ and were used as received. All the SOA proxies had $\mathrm{O} / \mathrm{C}$ values between 0.3 and 1.0 (Table S2), similar to SOA in the atmosphere. ${ }^{38}$ The SOA proxies had molecular weights ranging from 92 to $575 \mathrm{~g} \mathrm{~mol}^{-1}$, which is consistent with the range of molecular weight found in ambient SOA. ${ }^{94-97}$ Some of the SOA proxies have also been identified within ambient SOA, or SOA generated in chamber studies by the oxidation of atmospherically relevant VOCs, including glutaric acid and cis-pinonic acid. ${ }^{92,98,99}$ The SOA proxies had the following functional groups: carboxylic acids, esters, ketones, aromatics, alcohols, and ethers. All these functional groups have been identified in ambient organic aerosol, , $^{2,89-93}$ and compounds containing these functional groups have also been used previously as proxies of SOA in laboratory studies.

Generation of Solutions and Particles. Organic solutions containing equal amounts of POA and SOA by mass were prepared by mixing 1.75 wt $\%$ of POA and $1.75 \mathrm{wt}$ $\%$ SOA in high purity liquid chromatography grade ethyl acetate. For three of the POA surrogates used here, mixtures of two single-component commercially available organic compounds were made and used as POA proxies (see Table S1). The POA-to-SOA mass mixing ratio of 1:1 used here is a simplification but falls within the range observed in urban environments. ${ }^{1}$ Trace amounts $\left(\leq 10 \mathrm{mg} \mathrm{L}^{-1}\right)$ of Nile red (9diethylamino- $5 H$-benzo $[\alpha]$ phenoxazine-5-one) were added to the solutions in order to better identify multiple phases within the same particle using optical and fluorescence microscopy (see below). Next, the solutions were nebulized (Meinhard, TR-30-C0.5) using nitrogen as a carrier gas (grade 5.0, Linde). The aerosol stream was directed toward a glass slide (Hampton Research, HR3-209T, 12 mm diameter), resulting in the aerosols impacting and coagulating on the glass slide and forming supermicron particles. In order to achieve a high contact angle between the substrate and the solution droplets glass slides coated with FluoroPel-800 (Cytonix) or trichloro$(1 \mathrm{H}, 1 \mathrm{H}, 2 \mathrm{H}, 2 \mathrm{H}$-perfluorooctyl)silane (Sigma-Aldrich) were used. After impacting the aerosols on the glass slides, the ethyl acetate was evaporated in a fume hood, resulting in particles with diameters of approximately $40-120 \mu \mathrm{m}$, containing the specific POA and SOA proxies, along with Nile red. While this is larger than atmospheric organic aerosol, this size range allows the observation of the phase behavior in the clearest manner with our microscope setups, based on previous studies from our laboratory. ${ }^{100}$

Microscopy Analysis of Phase Behavior. The phase behavior of the POA + SOA particles was determined with optical and fluorescence microscopy. In most cases, we used optical microscopy to identify the number of phases in the POA + SOA particles. However, in a few cases (11 out of 273 


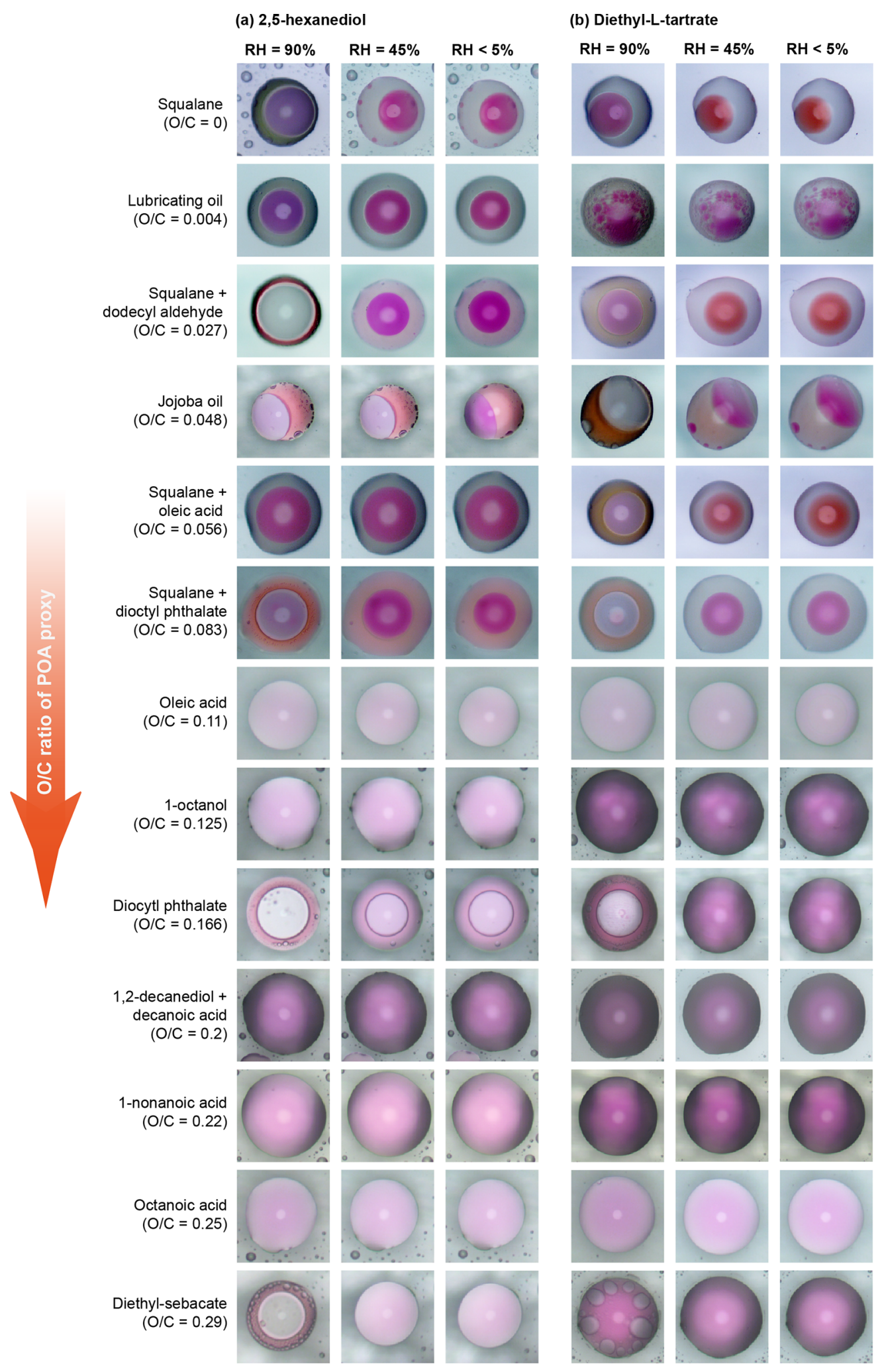

Figure 2. Examples of optical microscopy images of particles composed of mixtures of SOA and POA proxies. The POA proxies are indicated on the left, and the number in parenthesis indicates the elemental $\mathrm{O} / \mathrm{C}$ ratio. The proxies used to represent the SOA, indicated on the top of the figure, are (a) 2,5-hexanediol $(\mathrm{O} / \mathrm{C}=0.33)$ and $(\mathrm{b})$ diethyl-L-tartrate $(\mathrm{O} / \mathrm{C}=0.75)$. The individual columns correspond to different relative humidities $(\mathrm{RH})$. The red is due to trace amounts of Nile red embedded in the particles and the white circle in the center of most droplets results from an optical effect and is not due to separate phases. ${ }^{14}$ The diameter of the particles shown ranges between 60 and $90 \mu \mathrm{m}$. For phase-separated particles with a core-shell morphology, for example, when using a mixture of squalane and oleic acid as a POA proxy, the POA material formed the outer (shell) phase and SOA formed the inner (core) phase in most of the cases. See text for details. 


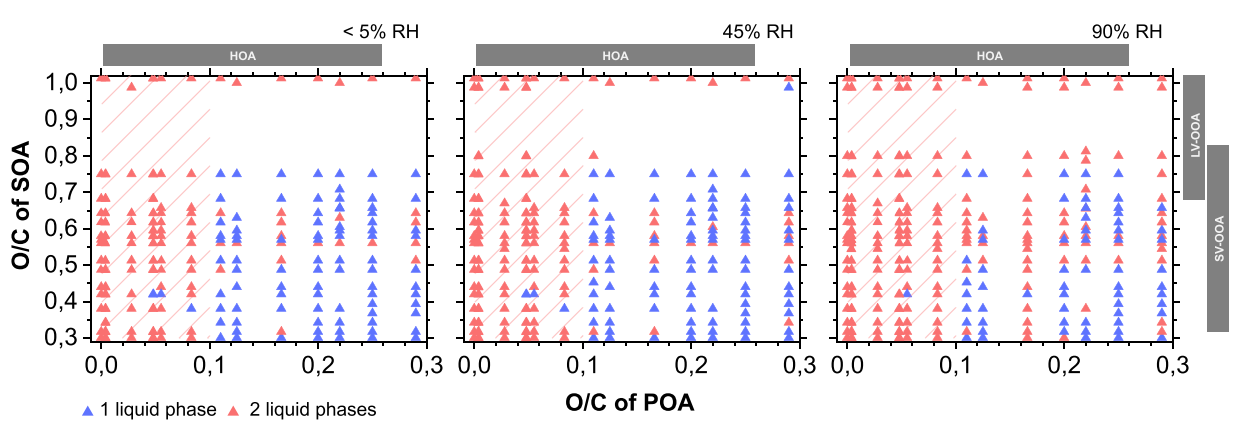

Figure 3. Number of liquid phases formed in different internal mixtures containing proxies of POA and SOA as a function of the $\mathrm{O} / \mathrm{C}$ of the organic components mixed, and at $\mathrm{RH}$ values of $<5 \%, 45 \%$, and $90 \%$, from left to right. Blue and red symbols indicate POA + SOA mixtures with one and two liquid phases, respectively (see also Table 2 and Figures S1-S3). Each data point represents results from a unique type of POA + SOA mixture comprising three to nine individual particles. If a solid phase was formed in a mixture at any of the RH values, the mixture was excluded from the analysis and not included here, as described in the text. Data points are vertically offset for clarity by values of at most 0.02 , in cases where multiple SOA proxies with the same $\mathrm{O} / \mathrm{C}$ were mixed with one POA proxy. The red hashed region in each panel depicts the $\mathrm{O} / \mathrm{C}$ range for which almost exclusively phase-separated particles were observed. The gray bars along the axes indicate the typical average $\mathrm{O} / \mathrm{C}$ range of atmospheric organic aerosol, classified as SV-OOA, LV-OOA, and HOA based on the classification in Canagaratna et al. ${ }^{38}$

Table 2. Summary of the Number of Phases Observed for the Mixtures of POA + SOA Proxies Investigated Herein at Three RH Values as Indicated ${ }^{a}$

\begin{tabular}{|c|c|c|c|c|c|c|}
\hline & \multicolumn{3}{|c|}{ POA: $\mathrm{O} / \mathrm{C}<0.11$} & \multicolumn{3}{|c|}{ POA: $0.11 \leq \mathrm{O} / \mathrm{C} \leq 0.29$} \\
\hline & $\mathrm{RH}=90 \%$ & $\mathrm{RH}=45 \%$ & $\mathrm{RH}<5 \%$ & $\mathrm{RH}=90 \%$ & $\mathrm{RH}=45 \%$ & $\mathrm{RH}<5 \%$ \\
\hline 2 phases & 108 & 97 & 82 & 72 & 30 & 25 \\
\hline 1 phase & 2 & 3 & 3 & 59 & 88 & 85 \\
\hline core-shell & 87 & 76 & 62 & 55 & 29 & 24 \\
\hline partially engulfed & 11 & 11 & 11 & 6 & 1 & 1 \\
\hline emulsified & 10 & 10 & 9 & 11 & 0 & 0 \\
\hline
\end{tabular}

${ }^{a}$ Also tabulated is the resulting POA + SOA morphology, that is, the number of mixtures that had a core-shell, partially engulfed, or emulsified structure. See Figures $\mathrm{S} 1-\mathrm{S} 3$ for details of the individual mixtures.

POA + SOA mixtures investigated, Table S3), we used fluorescence microscopy to confirm the results from the optical microscopy images.

In either case, a microscope (Bruker, Hyperion; Zeiss, AxioTech; or Olympus, IX70) was coupled to a temperature and RH-controlled flow cell, following previous work, ${ }^{101,102}$ and all the experiments were performed at a room temperature of $\sim 296 \pm 2 \mathrm{~K}$, monitored with a T-type thermocouple (Omega, model: FF-T-20-100). A gas stream $\left(\sim 1-2 \mathrm{~L} \mathrm{~min}^{-1}\right.$ of high purity $\mathrm{N}_{2}$ ) was continuously passed over the particles, and the water vapor mixing ratio of the gas stream was controlled by combining two flows, one containing dry $\mathrm{N}_{2}$ and another $\mathrm{N}_{2}$ flow that was humidified with a bubbler system. The $\mathrm{RH}$ was measured $\sim 10 \mathrm{~cm}$ downstream of the flow cell and images were captured at discrete $\mathrm{RH}$ values of $90 \%, 45 \%$, and below $5 \%$, respectively, using one of the microscopes. The experiments started at $90 \% \mathrm{RH}$, and the $\mathrm{RH}$ was then decreased stepwise to $45 \%$ and below $5 \%$. At all three $\mathrm{RH}$ values, the particles were equilibrated for at least $3 \mathrm{~min}$ prior to recording images. When switching between these $\mathrm{RH}$ levels, the particles were monitored and videos were recorded. These movies helped to better identify phase changes in some of the experiments, but the change in $\mathrm{RH}$ between our three $\mathrm{RH}$ values occurs too fast in most of our experiments to determine precisely the separation RH for liquid-liquid phase separation (LLPS), as reported in previous studies from our group. ${ }^{83}$ For all POA + SOA mixtures between 3 and 9 individual particles were monitored throughout a single experiment. All our experiments were performed for timescales on the order of minutes to hours, reducing the possibility of diffusion limitations preventing the mixing of POA and SOA.

\section{RESULTS AND DISCUSSION}

Depicted in Figure 2 are examples of optical images recorded in our experiments. Shown are images of all the POA proxies studied here mixed with two SOA proxies, namely, 2,5hexanediol $(\mathrm{O} / \mathrm{C}=0.33)$ and diethyl-L-tartrate $(\mathrm{O} / \mathrm{C}=0.75)$. These two SOA proxies fall within the $\mathrm{O} / \mathrm{C}$ range of fresh, moderately oxidized SOA (SV-OOA) and aged, strongly oxidized SOA (LV-OOA), respectively. The images allow us to determine when mixtures of POA and SOA form one- or twophase particles, and if the deposited POA + SOA particles have a core-shell, partially engulfed, or emulsified morphology. For all of the three $\mathrm{RH}$ values investigated and for both SOA proxies shown in Figure 2, two phases were observed when the POA had an $\mathrm{O} / \mathrm{C}<0.11$, while phase-separated particles were only occasionally observed for these two SOA proxies when the POA had $0.11 \leq \mathrm{O} / \mathrm{C} \leq 0.29$.

Shown in Figure 3 is a summary of the phase behavior for all the POA and SOA proxies studied here. This includes the POA proxies depicted in Figure 2, along with a large set of different SOA surrogates with different $\mathrm{O} / \mathrm{C}$ ratios, covering a range of molecular weights between $\sim 92$ and $\sim 575 \mathrm{~g} \mathrm{~mol}^{-1}$ and carbon numbers between 3 and 26 (see Table S1). Every data point represents the results from a unique type of $\mathrm{POA}+\mathrm{SOA}$ mixture. In some of the experiments, the SOA proxy crystallized. For example, crystallization was often observed when using the SOA proxy 2,5-dihydroxy benzoic acid $(\mathrm{O} / \mathrm{C}=$ 0.57 ), likely due to its high melting temperature (around 204 
${ }^{\circ} \mathrm{C}$ ). Crystalline particles can be identified from our microscopy images by their irregular (non-spherical) shape and occurrence of different structural patterns, resulting from the nucleation and growth process of the crystalline phase. In contrast, such irregular particle shapes and patterns are absent for highly viscous or glassy POA + SOA particles. We only include data points shown in Figure 3, for which both the POA proxy and the SOA proxy were present in a non-crystalline phase state at the indicated $\mathrm{RH}$ level, as determined from the optical images because in the atmosphere the crystallization of organics and mixtures thereof is most often not important. ${ }^{103}$ While we note that as the $\mathrm{RH}$ is decreased some organics can become highly viscous or even glassy, ${ }^{104-106}$ we continue to refer to these phases as liquid in our analysis and discussion below for convenience.

Figure 3 reveals a region in the $\mathrm{O} / \mathrm{C}$ phase space where twophase particles dominate for individual POA + SOA mixtures. More specifically, if the $\mathrm{O} / \mathrm{C}$ of the POA was below 0.11 , we almost exclusively observed two liquid phases in the POA + SOA particles, independent of the RH (see red hashed areas in Figure 3 and Table 2). This includes experiments with organic molecules with carboxylic acid, alcohol, and ester functional groups (see Table S2), which are known to be abundant in atmospheric SOA. $^{98,107}$ The only exceptions to this trend were $\mathrm{POA}+\mathrm{SOA}$ systems with either bis(2-ethoxyethyl)adipate $(\mathrm{O} / \mathrm{C}=0.42)$ or poly(propylene glycol) $425(\mathrm{O} / \mathrm{C}=0.38)$ as SOA proxies (see Figures $\mathrm{S} 1-\mathrm{S} 3$ for details). Both of these SOA compounds contain ether functionalities. However, several other SOA proxies that contained ether functionalities formed two liquid phases in the POA + SOA particles when the $\mathrm{O} / \mathrm{C}$ of the POA was below 0.11. In addition, ether functional groups have similar limits-of-miscibility in water compared to carboxyl and alcohol functional groups, according to thermodynamic modeling. ${ }^{68}$ Therefore, the presence of ether functionalities alone does not explain the two exceptions, bis(2-ethoxyethyl)adipate or poly(propylene glycol) 425 . Overall, the persistence of the two liquid phases observed in our study for $\mathrm{POA}$ with $\mathrm{O} / \mathrm{C}<0.11$ suggests that hydrocarbon-like POA species with low $\mathrm{O} / \mathrm{C}$ ratios often phase-separate from SV-OOA and LV-OOA materials, which have typical $\mathrm{O} / \mathrm{C}$ ratios ranging from 0.32 to $0.83^{38}$ and 0.68 to $1.32,{ }^{38}$ respectively, as indicated by the gray bars in Figure 3.

Figure 3 also shows that if the $\mathrm{O} / \mathrm{C}$ of the POA component is between 0.11 and 0.29 , one liquid phase was mostly observed. However, there is more variability in the results for $\mathrm{O} / \mathrm{C}$ between 0.11 and 0.29 compared to when the $\mathrm{O} / \mathrm{C}$ is below 0.11 . This apparent variability of the number of phases observed in this $\mathrm{O} / \mathrm{C}$ range suggests that other properties besides the $\mathrm{O} / \mathrm{C}$ are also important for determining the phase behavior of such POA + SOA particles. While the description of the phase behavior with further parameters in addition to $\mathrm{O} / \mathrm{C}$ is likely to increase the accuracy of predictions, it comes at the expense of adding complexity and is beyond the scope of the current study. On a related note, the Hansen solubility framework has been used to predict the phase behavior of POA + SOA particles. ${ }^{30,70}$ The Hansen solubility framework contains more chemical information than the O/C. For instance, the Hansen solubility parameter includes intramolecular attractions and functional groups of the components in a mixture. ${ }^{108}$

Another parameter that impacts the number of phases observed in $\mathrm{POA}+\mathrm{SOA}$ particles is the $\mathrm{RH}$, as shown in Figure 3. For POA proxies with $0.11 \leq \mathrm{O} / \mathrm{C} \leq 0.29$, the occurrence of the two liquid phases increased as the $\mathrm{RH}$ was increased (compare different panels in Figure 3). At high RH, a water-rich phase containing hydrophilic SOA compounds and a separated POA phase may be more thermodynamically favored compared to a single SOA + POA phase. Our results suggest that the effect of $\mathrm{RH}$ needs to be considered when predicting the phase behavior of the POA + SOA particles in atmospheric models. In a few studies with POA + SOA mixtures, LLPS has been observed as the RH increases. ${ }^{69,79,83}$ For example, Gorkowski et al. ${ }^{69,79}$ reported that mixtures of glycerol and $\alpha$-pinene SOA form single-phase particles at $12 \%$ $\mathrm{RH}$ but form two-phase particles at $73 \% \mathrm{RH}$.

As a side remark, in most cases, the morphology of the phase-separated particles revealed a core-shell structure. A summary of the observed morphologies is given in Table 2 and details for the individual POA + SOA mixtures are included in Figures S1-S3. In most cases, the hydrophobic POA phase was on the exterior of the particles, as can be inferred from the more oxidized and, hence, more hydrophilic SOA components decreasing in size due to the loss of water as the $\mathrm{RH}$ is decreased (e.g., images in Figure 2 when a mixture of squalane and dodecyl aldehyde are used as POA proxy). The equilibrium morphology of a phase-separated POA + SOA particle system suspended in air corresponds to the configuration with the lowest Gibbs free energy. For bi-phasic aerosol particles in air, the morphology with the lowest Gibbs free energy can be predicted from the liquid spreading coefficient framework, ${ }^{69,109}$ which determines the equilibrium morphology by minimizing the total surface tensions and interfacial tensions of a system. We note that our particles are deposited on hydrophobic glass slides, which could affect the resulting morphology. In our experiments, the particles were generated by nebulizing a solution of ethyl acetate containing the SOA and POA proxies, followed by the evaporation of ethyl acetate. Previous studies have shown that when SOA is condensed onto pre-existing hydrophobic POA particles or submicron SOA particles collide with micrometer-sized hydrophobic POA particles, the SOA material is located on the exterior of the particles. ${ }^{69,75,79}$ Hence, a configuration with SOA on the exterior of a POA core seems the most likely initial condition in the atmosphere. Cloud processing of SOA + POA particles could also change the morphology from SOA on the exterior of a POA core to POA on the exterior of a SOA core, depending on which morphology is the equilibrium morphology and the magnitude of any potential energy barriers to reaching the equilibrium morphology.

As mentioned above, several studies have investigated the phase behavior of internally mixed POA + SOA particles, often using more complex SOA material than the single-component organic proxies used herein. However, a majority of the past work has focused on either POA with $\mathrm{O} / \mathrm{C} \leq 0.09$ or used dioctyl phthalate as POA with an $\mathrm{O} / \mathrm{C}$ of 0.166 (see Figure 1 and Table 1). In addition, in only a few of these studies was the number of phases directly probed. For the other cases, mostly the miscibility of POA and SOA was probed, as indicated in Table 1 (column 4). For experiments where the number of phases was not directly probed, the authors determined either (i) SOA and POA were completely immiscible or (ii) SOA and POA were partially or completely miscible. In cases where SOA and POA were completely immiscible, two-phase particles can be inferred. In cases where the number of phases was not directly probed and the particles were reported to be partially or completely miscible, the number of phases was not 
fully constrained because complete miscibility corresponds to single-phase particles and partial miscibility corresponds to two-phase particles. In Table 1 (column 5), we have indicated the number of phases that were reported or could be inferred from the previous studies. Here, we compare our results with these studies in more detail, first focusing on the experiments that used POA with $\mathrm{O} / \mathrm{C} \leq 0.09$, and then focusing on the experiments that used dioctyl phthalate as a POA proxy with $\mathrm{O} / \mathrm{C}=0.166$.

The previous studies that used POA proxies with $\mathrm{O} / \mathrm{C} \leq$ 0.09 concluded in almost all the experiments (13 out of 16) that POA and chamber-generated SOA material derived from atmospherically relevant VOCs form two-phase particles (see Table 1). These results are consistent with our finding that two phases were observed in almost all the cases when the POA had $\mathrm{O} / \mathrm{C}<0.1$. The other three experiments in this $\mathrm{O} / \mathrm{C}$ range of the POA shown in Figure 1 were carried out by Ye et al. ${ }^{92}$ and Asa-Awuku et al. ${ }^{33}$ Ye et al. ${ }^{72}$ found that the yield of SOA mass from $\alpha$-pinene ozonolysis was enhanced in the presence of hexadecanol $(\mathrm{O} / \mathrm{C}=0.0625)$, meaning the SOA was partially or completely miscible in hexadecanol. In this case, the number of phases in the POA + SOA mixtures could have been one or two, which does not contradict our experiments. On a related note, in our experiments where two-phase particles were observed, partial miscibility between the POA and the SOA proxies may have occurred because partial miscibility cannot be distinguished from the complete immiscibility by our method. Asa-Awuku et al. ${ }^{33}$ used a smog chamber and investigated the mixing of SOA with POA from diesel engine exhaust, having an $\mathrm{O} / \mathrm{C}$ of 0.047 . They observed strong mixing and concluded that single-phase POA + SOA particles were formed. The observations from AsaAwuku et al. ${ }^{33}$ are not consistent with our results. Ye et al. ${ }^{70}$ investigated a similar type of mixture and reported no enhancement of SOA in the presence of diesel engine exhaust POA particles, suggesting phase-separated particles, in line with our findings. We conclude that additional field and laboratory studies with diesel engine exhaust POA are needed to resolve apparent discrepancies in the literature, given that diesel engine exhaust POA is an important source of HOA in the atmosphere.

Two studies have been performed with dioctyl phthalate as the POA proxy, which has an O/C of 0.166 (see Table 1). The chamber study by Song et al. ${ }^{73}$ investigated the enhancement of $\alpha$-pinene derived SOA in the presence of dioctyl phthalate seed particles. Vaden et al. $^{75}$ used single-particle mass spectrometry to investigate the phase behavior of the same POA + SOA system. In both studies, it was concluded that $\alpha$ pinene SOA and dioctyl phthalate form two phases when internally mixed. In our experiments, when the $\mathrm{O} / \mathrm{C}$ of the POA component was between 0.11 and 0.29 (which is the case for dioctyl phthalate), one liquid phase was mostly observed, but phase-separated particles were also observed, in particular, at $90 \% \mathrm{RH}$. Although this may appear as a contradiction, we point out that dioctyl phthalate is the POA proxy for which we observed the largest number of two-phase particles in this $\mathrm{O} / \mathrm{C}$ region when mixing with our single-component SOA proxies. Specifically, for dioctyl phthalate, we found that 18 out of 21,8 out of 21 , and 7 out of 21 of the POA + SOA mixtures formed two-phase particles at $\mathrm{RH} 90 \%, 45 \%$, and $<5 \%$, respectively. In contrast, for most of the other POA proxies with $\mathrm{O} / \mathrm{C} \geq 0.11$, the number of two-phase particles was significantly smaller at a given RH level (see Figures S1-S3). Therefore, we conclude that our results do not contradict these previous studies that used dioctyl phthalate as the POA proxy. Knowledge of the phase behavior, that is, the number and type of phases of POA + SOA particles and how it changes as a function of $\mathrm{RH}$, is needed for air pollution and climate predictions. Here, we investigated the phase behavior of the POA + SOA particles in terms of O/C at RH values of $90 \%, 45 \%$, and below 5\% using commercially available organic proxies and microscopy. Our study significantly expands the number of POA and SOA proxies studied, allowing for predictions of the number of phases in POA + SOA particles based on the $\mathrm{O} / \mathrm{C}$ ratios of the components involved.

For POA proxies with $\mathrm{O} / \mathrm{C}<0.11$ and SOA proxies with $\mathrm{O} / \mathrm{C} \geq 0.3$, two-phase particles were almost always observed. Our results in this $\mathrm{O} / \mathrm{C}$ range are consistent with earlier observations of more complex SOA generated in chamber studies. Taken together, the combined results challenge the assumption of a single phase for POA and SOA mixtures in previous modeling studies. Such assumptions most likely lead to an overestimation of the SOA mass when predicting atmospheric SOA formation. Thus, in urban areas close to the emission sources of the hydrocarbon-like organic aerosols, where the oxidation state of the POA is most likely low, POA mass will not likely enhance SOA formation to a large degree, with important implications for policies being considered to reduce SOA mass in urban environments.

For POA proxies with $0.11 \leq \mathrm{O} / \mathrm{C} \leq 0.29$ and SOA proxies with $\mathrm{O} / \mathrm{C} \geq 0.3$, in most cases, one phase was observed. Specifically, mostly SOA + POA particles with a single liquid phase were found for $\mathrm{RH}<5 \%$ and $45 \%$ but an increase in the number of two-phase systems was observed at $90 \% \mathrm{RH}$. We conclude that POA with $\mathrm{O} / \mathrm{C}$ values in this range may mix with SOA to form internally mixed aerosol particles with a single liquid phase and enhance the formation of SOA in an urban environment. While we refer to the phases as liquid throughout this document, we note that as the $\mathrm{RH}$ is decreased some organics can become highly viscous or even glassy. In addition, we conclude that $\mathrm{RH}$ will likely be most important for the phase behavior only at the highest $\mathrm{RH}$ values.

We point out that there remain a number of challenges for future studies to address. Our experiments have focused on supermicron sized particles. While atmospheric organic aerosol particles mostly have diameters in the sub-micrometer range, we expect that the phase behavior observed here for particles with diameters of $40-120 \mu \mathrm{m}$ are transferrable to POA + SOA particles with diameters down to around $40 \mathrm{~nm} .{ }^{110}$ If the diameter is less than $\sim 40 \mathrm{~nm}$, phase separation can become volume restricted. ${ }^{111}$ At the same time, we acknowledge that the $\mathrm{RH}$ at which LLPS takes place might be lower for supermicron compared to submicron particles. ${ }^{112,113}$ Hence, further studies are required to better understand the effect of particle size on the phase behavior of POA + SOA mixtures. In addition, the POA-to-SOA mass mixing ratio of 1:1 used here is a simplification and varies depending on the location and season, but falls within the range observed in urban environments. ${ }^{1}$ Hence, carrying out similar experiments as presented here but varying the mass mixing ratios of the POA and SOA proxies would benefit our understanding of the phase behavior of POA + SOA particles. Most importantly, it will be crucial to extend experiments as performed here to more realistic atmospheric POA and SOA materials in order to confirm our conclusions and to extrapolate these laboratory studies to atmospheric conditions with high confidence. 
Based on the discussion above and until additional data become available, we assume that our results can be extrapolated to the real atmosphere and to aerosol particles with sizes greater than $\sim 40 \mathrm{~nm}$. As a first order approximation, it seems reasonable to assume two liquid phases in POA + SOA particles, if $\mathrm{POA}$ has $\mathrm{O} / \mathrm{C}<0.11$ and one liquid phase for POA with $0.11 \leq \mathrm{O} / \mathrm{C} \leq 0.29$, independent of $\mathrm{RH}$. Additional studies with more complex atmospheric POA and SOA are needed to confirm these conclusions.

\section{ASSOCIATED CONTENT}

\section{SI Supporting Information}

The Supporting Information is available free of charge at https://pubs.acs.org/doi/10.1021/acs.est.1c02697.

Overview of compounds used as hydrocarbon-like POA and SOA proxies, list of POA+SOA internal mixtures analyzed by fluorescence microscopy, and the number of phases observed for particles containing mixtures of SOA and POA (PDF)

\section{AUTHOR INFORMATION}

\section{Corresponding Author}

Allan K. Bertram - Department of Chemistry, University of British Columbia, Vancouver, British Columbia V6T1Z1, Canada; 이이이.org/0000-0002-5621-2323;

Email: bertram@chem.ubc.ca

\section{Authors}

Fabian Mahrt - Department of Chemistry, University of British Columbia, Vancouver, British Columbia V6T1Z1, Canada; Laboratory of Environmental Chemistry, Paul Scherrer Institute, 5232 Villigen, Switzerland; (o orcid.org/ 0000-0002-7059-6765

Elli Newman - Department of Chemistry, University of British Columbia, Vancouver, British Columbia V6T1Z1, Canada; Present Address: Department of Applied Chemistry, Keio University, 3-14-1 Hiyoshi, Kohokuku, Yokohama, 2238522, Japan

Yuanzhou Huang - Department of Chemistry, University of British Columbia, Vancouver, British Columbia V6T1Z1, Canada; Present Address: Anton Paar Canada Inc., 4920 Place Olivia, H4R 2Z8 Saint Laurent.

Markus Ammann - Laboratory of Environmental Chemistry, Paul Scherrer Institute, 5232 Villigen, Switzerland; ๑ orcid.org/0000-0001-5922-9000

Complete contact information is available at: https://pubs.acs.org/10.1021/acs.est.1c02697

\section{Author Contributions}

F.M. prepared all the figures and wrote the manuscript with the help of A.K.B. E.N. and Y.H. performed experiments with help and supervision from F.M. F.M., A.K.B., and M.A. discussed and interpreted data, and all the authors have given their approval to the final version of the manuscript. A.K.B. oversaw the project.

\section{Funding}

E.N., A.K.B., and F.M. acknowledge funding through the Work Learn International Undergraduate Research Award (grant agreement No. 10045). A.K.B. further acknowledges funding from Natural Sciences and Engineering Research Council of Canada (NSERC) through the grant RGPIN/04441-2016. This work was part of a project that received funding from the
European Union's Horizon 2020 research and innovation program under the Marie Skłodowska-Curie grant agreement no. 890200 (F.M.) hosted at PSI and UBC.

\section{Notes}

The authors declare no competing financial interest.

\section{ACKNOWLEDGMENTS}

The authors acknowledge Jenny Lai and Dr. Yun Ling from the mass spectrometry facility at UBC for help with elemental analysis. The authors thank Lauren Koch for help with proofreading.

\section{ABBREVIATIONS}

LLPS liquid-liquid phase separation

$\mathrm{RH}$ relative humidity

$T$ temperature

POA primary organic aerosol

SOA secondary organic aerosol

HOA hydrocarbon-like organic aerosol

$\mathrm{O} / \mathrm{C}$ elemental oxygen-to-carbon ratio

$\mathrm{PM}$ particulate matter

\section{REFERENCES}

(1) Jimenez, J. L.; Canagaratna, M. R.; Donahue, N. M.; Prevot, A. S. H.; Zhang, Q.; Kroll, J. H.; DeCarlo, P. F.; Allan, J. D.; Coe, H.; Ng, N. L.; Aiken, A. C.; Docherty, K. S.; Ulbrich, I. M.; Grieshop, A. P.; Robinson, A. L.; Duplissy, J.; Smith, J. D.; Wilson, K. R.; Lanz, V. A.; Hueglin, C.; Sun, Y. L.; Tian, J.; Laaksonen, A.; Raatikainen, T.; Rautiainen, J.; Vaattovaara, P.; Ehn, M.; Kulmala, M.; Tomlinson, J. M.; Collins, D. R.; Cubison, M. J.; Dunlea, J.; Huffman, J. A.; Onasch, T. B.; Alfarra, M. R.; Williams, P. I.; Bower, K.; Kondo, Y.; Schneider, J.; Drewnick, F.; Borrmann, S.; Weimer, S.; Demerjian, K.; Salcedo, D.; Cottrell, L.; Griffin, R.; Takami, A.; Miyoshi, T.; Hatakeyama, S.; Shimono, A.; Sun, J. Y.; Zhang, Y. M.; Dzepina, K.; Kimmel, J. R.; Sueper, D.; Jayne, J. T.; Herndon, S. C.; Trimborn, A. M.; Williams, L. R.; Wood, E. C.; Middlebrook, A. M.; Kolb, C. E.; Baltensperger, U.; Worsnop, D. R. Evolution of Organic Aerosols in the Atmosphere. Science 2009, 326, 1525-1529.

(2) Seinfeld, J. H.; Pankow, J. F. Organic Atmospheric Particulate Material. Annu. Rev. Phys. Chem. 2003, 54, 121-140.

(3) Zhang, Q.; Jimenez, J. L.; Canagaratna, M. R.; Allan, J. D.; Coe, H.; Ulbrich, I.; Alfarra, M. R.; Takami, A.; Middlebrook, A. M.; Sun, Y. L.; Dzepina, K.; Dunlea, E.; Docherty, K.; DeCarlo, P. F.; Salcedo, D.; Onasch, T.; Jayne, J. T.; Miyoshi, T.; Shimono, A.; Hatakeyama, S.; Takegawa, N.; Kondo, Y.; Schneider, J.; Drewnick, F.; Borrmann, S.; Weimer, S.; Demeriian, K.; Williams, P.; Bower, K.; Bahreini, R.; Cottrell, L.; Griffin, R. J.; Rautiainen, J.; Sun, J. Y.; Zhang, Y. M.; Worsnop, D. R. Ubiquity and Dominance of Oxygenated Species in Organic Aerosols in Anthropogenically-Influenced Northern Hemisphere Midlatitudes. Geophys. Res. Lett. 2007, 34, L13801.

(4) Zhang, Q.; Jimenez, J. L.; Canagaratna, M. R.; Ulbrich, I. M.; Ng, N. L.; Worsnop, D. R.; Sun, Y. Understanding Atmospheric Organic Aerosols via Factor Analysis of Aerosol Mass Spectrometry: A Review. Anal. Bioanal. Chem. 2011, 401, 3045-3067.

(5) Kanakidou, M.; Seinfeld, J. H.; Pandis, S. N.; Barnes, I.; Dentener, F. J.; Facchini, M. C.; Van Dingenen, R.; Ervens, B.; Nenes, A.; Nielsen, C. J.; Swietlicki, E.; Putaud, J. P.; Balkanski, Y.; Fuzzi, S.; Horth, J.; Moortgat, G. K.; Winterhalter, R.; Myhre, C. E. L.; Tsigaridis, K.; Vignati, E.; Stephanou, E. G.; Wilson, J. Organic Aerosol and Global Climate Modelling: A Review. Atmos. Chem. Phys. 2005, 5, 1053-1123.

(6) Jacobson, M. C.; Hansson, H.-C.; Noone, K. J.; Charlson, R. J. Organic Atmospheric Aerosols: Review and State of the Science. Rev. Geophys. 2000, 38, 267-294. 
(7) Abbatt, J. P. D.; Lee, A. K. Y.; Thornton, J. A. Quantifying Trace Gas Uptake to Tropospheric Aerosol: Recent Advances and Remaining Challenges. Chem. Soc. Rev. 2012, 41, 6555-6581.

(8) Pöschl, U.; Shiraiwa, M. Multiphase Chemistry at the Atmosphere-Biosphere Interface Influencing Climate and Public Health in the Anthropocene. Chem. Rev. 2015, 115, 4440-4475.

(9) Shiraiwa, M.; Ammann, M.; Koop, T.; Pöschl, U. Gas Uptake and Chemical Aging of Semisolid Organic Aerosol Particles. Proc. Natl. Acad. Sci. U.S.A. 2011, 108, 11003-11008.

(10) Huang, R.-J.; Zhang, Y.; Bozzetti, C.; Ho, K.-F.; Cao, J.-J.; Han, Y.; Daellenbach, K. R.; Slowik, J. G.; Platt, S. M.; Canonaco, F.; Zotter, P.; Wolf, R.; Pieber, S. M.; Bruns, E. A.; Crippa, M.; Ciarelli, G.; Piazzalunga, A.; Schwikowski, M.; Abbaszade, G.; Schnelle-Kreis, J.; Zimmermann, R.; An, Z.; Szidat, S.; Baltensperger, U.; Haddad, I. E.; Prévôt, A. S. H. High Secondary Aerosol Contribution to Particulate Pollution during Haze Events in China. Nature 2014, 514, 218-222.

(11) Volkamer, R.; Jimenez, J. L.; San Martini, F.; Dzepina, K.; Zhang, Q.; Salcedo, D.; Molina, L. T.; Worsnop, D. R.; Molina, M. J. Secondary Organic Aerosol Formation from Anthropogenic Air Pollution: Rapid and Higher than Expected. Geophys. Res. Lett. 2006, 33, L17811.

(12) Baltensperger, U.; Dommen, J.; Alfarra, M. R.; Duplissy, J.; Gaeggeler, K.; Metzger, A.; Facchini, M. C.; Decesari, S.; Finessi, E.; Reinnig, C.; Schott, M.; Warnke, J.; Hoffmann, T.; Klatzer, B.; Puxbaum, H.; Geiser, M.; Savi, M.; Lang, D.; Kalberer, M.; Geiser, T. Combined Determination of the Chemical Composition and of Health Effects of Secondary Organic Aerosols: The POLYSOA Project. J. Aerosol Med. Pulm. Drug Delivery 2008, 21, 145-154.

(13) Lelieveld, J.; Evans, J. S.; Fnais, M.; Giannadaki, D.; Pozzer, A. The Contribution of Outdoor Air Pollution Sources to Premature Mortality on a Global Scale. Nature 2015, 525, 367-371.

(14) Shiraiwa, M.; Ueda, K.; Pozzer, A.; Lammel, G.; Kampf, C. J.; Fushimi, A.; Enami, S.; Arangio, A. M.; Fröhlich-Nowoisky, J.; Fujitani, Y.; Furuyama, A.; Lakey, P. S. J.; Lelieveld, J.; Lucas, K.; Morino, Y.; Pöschl, U.; Takahama, S.; Takami, A.; Tong, H.; Weber, B.; Yoshino, A.; Sato, K. Aerosol Health Effects from Molecular to Global Scales. Environ. Sci. Technol. 2017, 51, 13545-13567.

(15) Shrivastava, M.; Lou, S.; Zelenyuk, A.; Easter, R. C.; Corley, R. A.; Thrall, B. D.; Rasch, P. J.; Fast, J. D.; Massey Simonich, S. L.; Shen, H.; Tao, S. Global Long-Range Transport and Lung Cancer Risk from Polycyclic Aromatic Hydrocarbons Shielded by Coatings of Organic Aerosol. Proc. Natl. Acad. Sci. U.S.A. 2017, 114, 1246-1251. (16) Nault, B. A.; Jo, D. S.; McDonald, B. C.; Campuzano-Jost, P.; Day, D. A.; Hu, W.; Schroder, J. C.; Allan, J.; Blake, D. R.; Canagaratna, M. R.; Coe, H.; Coggon, M. M.; DeCarlo, P. F.; Diskin, G. S.; Dunmore, R.; Flocke, F.; Fried, A.; Gilman, J. B.; Gkatzelis, G.; Hamilton, J. F.; Hanisco, T. F.; Hayes, P. L.; Henze, D. K.; Hodzic, A.; Hopkins, J.; Hu, M.; Huey, L. G.; Jobson, B. T.; Kuster, W. C.; Lewis, A.; Li, M.; Liao, J.; Nawaz, M. O.; Pollack, I. B.; Peischl, J.; Rappenglück, B.; Reeves, C. E.; Richter, D.; Roberts, J. M.; Ryerson, T. B.; Shao, M.; Sommers, J. M.; Walega, J.; Warneke, C.; Weibring, P.; Wolfe, G. M.; Young, D. E.; Yuan, B.; Zhang, Q.; de Gouw, J. A.; Jimenez, J. L. Secondary organic aerosols from anthropogenic volatile organic compounds contribute substantially to air pollution mortality. Atmos. Chem. Phys. 2020, 21, 11201-11224.

(17) Knopf, D. A.; Alpert, P. A.; Wang, B. The Role of Organic Aerosol in Atmospheric Ice Nucleation: A Review. ACS Earth Space Chem. 2018, 2, 168.

(18) Shrivastava, M.; Cappa, C. D.; Fan, J.; Goldstein, A. H.; Guenther, A. B.; Jimenez, J. L.; Kuang, C.; Laskin, A.; Martin, S. T.; Ng, N. L.; Petaja, T.; Pierce, J. R.; Rasch, P. J.; Roldin, P.; Seinfeld, J. H.; Shilling, J.; Smith, J. N.; Thornton, J. A.; Volkamer, R.; Wang, J.; Worsnop, D. R.; Zaveri, R. A.; Zelenyuk, A.; Zhang, Q. Recent Advances in Understanding Secondary Organic Aerosol: Implications for Global Climate Forcing. Rev. Geophys. 2017, 55, 509-559.

(19) Goldstein, A. H.; Galbally, I. E. Known and Unexplored Organic Constituents in the Earth's Atmosphere. Environ. Sci. Technol. 2007, 41, 1514-1521.
(20) Ditto, J. C.; Barnes, E. B.; Khare, P.; Takeuchi, M.; Joo, T.; Bui, A. A. T.; Lee-Taylor, J.; Eris, G.; Chen, Y.; Aumont, B.; Jimenez, J. L.; Ng, N. L.; Griffin, R. J.; Gentner, D. R. An Omnipresent Diversity and Variability in the Chemical Composition of Atmospheric Functionalized Organic Aerosol. Commun. Chem. 2018, 1, 1-13.

(21) Finlayson-Pitts, B. J.; Wingen, L. M.; Perraud, V.; Ezell, M. J. Open Questions on the Chemical Composition of Airborne Particles. Commun. Chem. 2020, 3, 1-5.

(22) Nozière, B.; Kalberer, M.; Claeys, M.; Allan, J.; D’Anna, B.; Decesari, S.; Finessi, E.; Glasius, M.; Grgic, I.; Hamilton, J. F.; Hoffmann, T.; Iinuma, Y.; Jaoui, M.; Kahnt, A.; Kampf, C. J.; Kourtchev, I.; Maenhaut, W.; Marsden, N.; Saarikoski, S.; SchnelleKreis, J.; Surratt, J. D.; Szidat, S.; Szmigielski, R.; Wisthaler, A. The Molecular Identification of Organic Compounds in the Atmosphere: State of the Art and Challenges. Chem. Rev. 2015, 115, 3919-3983.

(23) Hallquist, M.; Wenger, J. C.; Baltensperger, U.; Rudich, Y.; Simpson, D.; Claeys, M.; Dommen, J.; Donahue, N. M.; George, C.; Goldstein, A. H.; Hamilton, J. F.; Herrmann, H.; Hoffmann, T.; Iinuma, Y.; Jang, M.; Jenkin, M. E.; Jimenez, J. L.; Kiendler-Scharr, A.; Maenhaut, W.; McFiggans, G.; Mentel, T. F.; Monod, A.; Prévôt, A. S. H.; Seinfeld, J. H.; Surratt, J. D.; Szmigielski, R.; Wildt, J. The Formation, Properties and Impact of Secondary Organic Aerosol: Current and Emerging Issues. Atmos. Chem. Phys. 2009, 9, 51555236.

(24) Tkacik, D. S.; Presto, A. A.; Donahue, N. M.; Robinson, A. L. Secondary Organic Aerosol Formation from Intermediate-Volatility Organic Compounds: Cyclic, Linear, and Branched Alkanes. Environ. Sci. Technol. 2012, 46, 8773-8781.

(25) Kroll, J. H.; Seinfeld, J. H. Chemistry of Secondary Organic Aerosol: Formation and Evolution of Low-Volatility Organics in the Atmosphere. Atmos. Environ. 2008, 42, 3593-3624.

(26) Robinson, A. L.; Donahue, N. M.; Shrivastava, M. K.; Weitkamp, E. A.; Sage, A. M.; Grieshop, A. P.; Lane, T. E.; Pierce, J. R.; Pandis, S. N. Rethinking Organic Aerosols: Semivolatile Emissions and Photochemical Aging. Science 2007, 315, 1259-1262.

(27) Ervens, B.; Turpin, B. J.; Weber, R. J. Secondary Organic Aerosol Formation in Cloud Droplets and Aqueous Particles (AqSOA): A Review of Laboratory, Field and Model Studies. Atmos. Chem. Phys. 2011, 11, 11069-11102.

(28) McNeill, V. F. Aqueous Organic Chemistry in the Atmosphere: Sources and Chemical Processing of Organic Aerosols. Environ. Sci. Technol. 2015, 49, 1237-1244.

(29) Brook, J. R.; Graham, L.; Charland, J. P.; Cheng, Y.; Fan, X.; Lu, G.; Li, S. M.; Lillyman, C.; MacDonald, P.; Caravaggio, G.; MacPhee, J. A. Investigation of the Motor Vehicle Exhaust Contribution to Primary Fine Particle Organic Carbon in Urban Air. Atmos. Environ. 2007, 41, 119-135.

(30) Ye, Q.; Gu, P.; Li, H. Z.; Robinson, E. S.; Lipsky, E.; Kaltsonoudis, C.; Lee, A. K. Y.; Apte, J. S.; Robinson, A. L.; Sullivan, R. C.; Presto, A. A.; Donahue, N. M. Spatial Variability of Sources and Mixing State of Atmospheric Particles in a Metropolitan Area. Environ. Sci. Technol. 2018, 52, 6807-6815.

(31) Collier, S.; Zhou, S.; Kuwayama, T.; Forestieri, S.; Brady, J.; Zhang, M.; Kleeman, M.; Cappa, C.; Bertram, T.; Zhang, Q. Organic PM Emissions from Vehicles: Composition, O/C Ratio, and Dependence on PM Concentration. Aerosol Sci. Technol. 2015, 49, 86-97.

(32) Alfarra, M. R.; Coe, H.; Allan, J. D.; Bower, K. N.; Boudries, H.; Canagaratna, M. R.; Jimenez, J. L.; Jayne, J. T.; Garforth, A. A.; Li, S.M.; Worsnop, D. R. Characterization of Urban and Rural Organic Particulate in the Lower Fraser Valley Using Two Aerodyne Aerosol Mass Spectrometers. Atmos. Environ. 2004, 38, 5745-5758.

(33) Asa-Awuku, A.; Miracolo, M. A.; Kroll, J. H.; Robinson, A. L.; Donahue, N. M. Mixing and Phase Partitioning of Primary and Secondary Organic Aerosols. Geophys. Res. Lett. 2009, 36, L15827.

(34) Worton, D. R.; Isaacman, G.; Gentner, D. R.; Dallmann, T. R.; Chan, A. W. H.; Ruehl, C.; Kirchstetter, T. W.; Wilson, K. R.; Harley, R. A.; Goldstein, A. H. Lubricating Oil Dominates Primary Organic 
Aerosol Emissions from Motor Vehicles. Environ. Sci. Technol. 2014, 48, 3698-3706.

(35) Canagaratna, M. R.; Jayne, J. T.; Ghertner, D. A.; Herndon, S.; Shi, Q.; Jimenez, J. L.; Silva, P. J.; Williams, P.; Lanni, T.; Drewnick, F.; Demerjian, K. L.; Kolb, C. E.; Worsnop, D. R. Chase Studies of Particulate Emissions from In-Use New York City Vehicles. Aerosol Sci. Technol. 2004, 38, 555-573.

(36) Tobias, H. J.; Beving, D. E.; Ziemann, P. J.; Sakurai, H.; Zuk, M.; McMurry, P. H.; Zarling, D.; Waytulonis, R.; Kittelson, D. B. Chemical Analysis of Diesel Engine Nanoparticles Using a NanoDMA/Thermal Desorption Particle Beam Mass Spectrometer. Environ. Sci. Technol. 2001, 35, 2233-2243.

(37) Sakurai, H.; Tobias, H. J.; Park, K.; Zarling, D.; Docherty, K. S.; Kittelson, D. B.; McMurry, P. H.; Ziemann, P. J. On-Line Measurements of Diesel Nanoparticle Composition and Volatility. Atmos. Environ. 2003, 37, 1199-1210.

(38) Canagaratna, M. R.; Jimenez, J. L.; Kroll, J. H.; Chen, Q.; Kessler, S. H.; Massoli, P.; Hildebrandt Ruiz, L.; Fortner, E.; Williams, L. R.; Wilson, K. R.; Surratt, J. D.; Donahue, N. M.; Jayne, J. T.; Worsnop, D. R. Elemental Ratio Measurements of Organic Compounds Using Aerosol Mass Spectrometry: Characterization, Improved Calibration, and Implications. Atmos. Chem. Phys. 2015, 15, 253-272.

(39) Carbone, S.; Timonen, H. J.; Rostedt, A.; Happonen, M.; Rönkkö, T.; Keskinen, J.; Ristimaki, J.; Korpi, H.; Artaxo, P.; Canagaratna, M.; Worsnop, D.; Canonaco, F.; Prévôt, A. S. H.; Hillamo, R.; Saarikoski, S. Distinguishing Fuel and Lubricating Oil Combustion Products in Diesel Engine Exhaust Particles. Aerosol Sci. Technol. 2019, 53, 594-607.

(40) Chen, Q.; Heald, C. L.; Jimenez, J. L.; Canagaratna, M. R.; Zhang, Q.; He, L. Y.; Huang, X. F.; Campuzano-Jost, P.; Palm, B. B.; Poulain, L.; Kuwata, M.; Martin, S. T.; Abbatt, J. P. D.; Lee, A. K. Y.; Liggio, J. Elemental Composition of Organic Aerosol: The Gap between Ambient and Laboratory Measurements. Geophys. Res. Lett. 2015, 42, 4182-4189.

(41) Reşitoğlu, İ. A.; Altinişik, K.; Keskin, A. The Pollutant Emissions from Diesel-Engine Vehicles and Exhaust Aftertreatment Systems. Clean Technol. Environ. Policy 2015, 17, 15-27.

(42) Liggio, J.; Li, S.-M.; Vlasenko, A.; Sjostedt, S.; Chang, R.; Shantz, N.; Abbatt, J.; Slowik, J. G.; Bottenheim, J. W.; Brickell, P. C.; Stroud, C.; Leaitch, W. R. Primary and Secondary Organic Aerosols in Urban Air Masses Intercepted at a Rural Site. J. Geophys. Res.: Atmos. 2010, 115, D21305.

(43) Riemer, N.; Ault, A. P.; West, M.; Craig, R. L.; Curtis, J. H. Aerosol Mixing State: Measurements, Modeling, and Impacts. Rev. Geophys. 2019, 57, 187-249.

(44) Murphy, D. M.; Cziczo, D. J.; Froyd, K. D.; Hudson, P. K.; Matthew, B. M.; Middlebrook, A. M.; Peltier, R. E.; Sullivan, A.; Thomson, D. S.; Weber, R. J. Single-Particle Mass Spectrometry of Tropospheric Aerosol Particles. J. Geophys. Res.: Atmos. 2006, 111, D23S32.

(45) Pratt, K. A.; Prather, K. A. Aircraft Measurements of Vertical Profiles of Aerosol Mixing States. J. Geophys. Res.: Atmos. 2010, 115, D11305.

(46) Vester, B.; Ebert, M.; Barnert, E.; Schneider, J.; Kandler, K.; Schütz, L.; Weinbruch, S. Composition and Mixing State of the Urban Background Aerosol in the Rhein-Main Area (Germany). Atmos. Environ. 2007, 41, 6102-6115.

(47) Marcolli, C.; Luo, B. P.; Peter, T.; Wienhold, F. G. Internal Mixing of the Organic Aerosol by Gas Phase Diffusion of Semivolatile Organic Compounds. Atmos. Chem. Phys. 2004, 4, 2593-2599.

(48) Cross, E. S.; Onasch, T. B.; Canagaratna, M.; Jayne, J. T.; Kimmel, J.; Yu, X.-Y.; Alexander, M. L.; Worsnop, D. R.; Davidovits, P. Single Particle Characterization Using a Light Scattering Module Coupled to a Time-of-Flight Aerosol Mass Spectrometer. Atmos. Chem. Phys. 2009, 9, 7769-7793.

(49) Moffet, R. C.; Prather, K. A. In-Situ Measurements of the Mixing State and Optical Properties of Soot with Implications for
Radiative Forcing Estimates. Proc. Natl. Acad. Sci. U.S.A. 2009, 106, $11872-11877$.

(50) Pankow, J. F. An Absorption-Model of Gas-Particle Partitioning of Organic-Compounds in the Atmosphere. Atmos. Environ. 1994, 28, $185-188$.

(51) Raoult, F.-M. Lois Générales de l'ébulliométrie. C. R. Phys. 1887, 104, 1430-1433.

(52) Carlton, A. G.; Pye, H. O. T.; Baker, K. R.; Hennigan, C. J. Additional Benefits of Federal Air-Quality Rules: Model Estimates of Controllable Biogenic Secondary Organic Aerosol. Environ. Sci. Technol. 2018, 52, 9254-9265.

(53) Cosman, L. M.; Knopf, D. A.; Bertram, A. K. N2O5 Reactive Uptake on Aqueous Sulfuric Acid Solutions Coated with Branched and Straight-Chain Insoluble Organic Surfactants. J. Phys. Chem. A 2008, 112, 2386-2396.

(54) Kuwata, M.; Martin, S. T. Phase of Atmospheric Secondary Organic Material Affects Its Reactivity. Proc. Natl. Acad. Sci. U.S.A. 2012, 109, 17354-17359.

(55) Mozurkewich, M.; Calvert, J. G. Reaction Probability of N2O5 on Aqueous Aerosols. J. Geophys. Res.: Atmos. 1988, 93, 1588915896.

(56) Schmedding, R.; Ma, M.; Zhang, Y.; Farrell, S.; Pye, H. O. T.; Chen, Y.; Wang, C.-t.; Rasool, Q. Z.; Budisulistiorini, S. H.; Ault, A. P.; Surratt, J. D.; Vizuete, W. $\alpha$-Pinene-Derived Organic Coatings on Acidic Sulfate Aerosol Impacts Secondary Organic Aerosol Formation from Isoprene in a Box Model. Atmos. Environ. 2019, 213, 456-462.

(57) Zhang, Y.; Chen, Y.; Lambe, A. T.; Olson, N. E.; Lei, Z.; Craig, R. L.; Zhang, Z.; Gold, A.; Onasch, T. B.; Jayne, J. T.; Worsnop, D. R.; Gaston, C. J.; Thornton, J. A.; Vizuete, W.; Ault, A. P.; Surratt, J. D. Effect of the Aerosol-Phase State on Secondary Organic Aerosol Formation from the Reactive Uptake of Isoprene-Derived Epoxydiols (IEPOX). Environ. Sci. Technol. Lett. 2018, 5, 167-174.

(58) Shiraiwa, M.; Zuend, A.; Bertram, A. K.; Seinfeld, J. H. GasParticle Partitioning of Atmospheric Aerosols: Interplay of Physical State, Non-Ideal Mixing and Morphology. Phys. Chem. Chem. Phys. 2013, 15, 11441-11453.

(59) Altaf, M. B.; Dutcher, D. D.; Raymond, T. M.; Freedman, M. A. Effect of Particle Morphology on Cloud Condensation Nuclei Activity. ACS Earth Space Chem. 2018, 2, 634-639.

(60) Ovadnevaite, J.; Zuend, A.; Laaksonen, A.; Sanchez, K. J.; Roberts, G.; Ceburnis, D.; Decesari, S.; Rinaldi, M.; Hodas, N.; Facchini, M. C.; Seinfeld, J. H.; O’ Dowd, C. Surface Tension Prevails over Solute Effect in Organic-Influenced Cloud Droplet Activation. Nature 2017, 546, 637-641.

(61) Renbaum-Wolff, L.; Song, M.; Marcolli, C.; Zhang, Y.; Liu, P. F.; Grayson, J. W.; Geiger, F. M.; Martin, S. T.; Bertram, A. K. Observations and Implications of Liquid-Liquid Phase Separation at High Relative Humidities in Secondary Organic Material Produced by $\alpha$-Pinene Ozonolysis without Inorganic Salts. Atmos. Chem. Phys. 2016, 16, 7969-7979.

(62) Rastak, N.; Pajunoja, A.; Acosta Navarro, J. C.; Ma, J.; Song, M.; Partridge, D. G.; Kirkevåg, A.; Leong, Y.; Hu, W. W.; Taylor, N. F.; Lambe, A.; Cerully, K.; Bougiatioti, A.; Liu, P.; Krejci, R.; Petäjä, T.; Percival, C.; Davidovits, P.; Worsnop, D. R.; Ekman, A. M. L.; Nenes, A.; Martin, S.; Jimenez, J. L.; Collins, D. R.; Topping, D. O.; Bertram, A. K.; Zuend, A.; Virtanen, A.; Riipinen, I. Microphysical Explanation of the RH-Dependent Water Affinity of Biogenic Organic Aerosol and Its Importance for Climate. Geophys. Res. Lett. 2017, 44, 5167-5177.

(63) Liu, P.; Song, M.; Zhao, T.; Gunthe, S. S.; Ham, S.; He, Y.; Qin, Y. M.; Gong, Z.; Amorim, J. C.; Bertram, A. K.; Martin, S. T. Resolving the Mechanisms of Hygroscopic Growth and Cloud Condensation Nuclei Activity for Organic Particulate Matter. Nat. Commun. 2018, 9, 1-10.

(64) Huang, Y.; Mahrt, F.; Xu, S.; Shiraiwa, M.; Zuend, A.; Bertram, A. K. Coexistence of Three Liquid Phases in Individual Atmospheric Aerosol Particles. Proc. Natl. Acad. Sci. 2021, 118, No. e2102512118. 
(65) Odum, J. R.; Hoffmann, T.; Bowman, F.; Collins, D.; Flagan, R. C.; Seinfeld, J. H. Gas/Particle Partitioning and Secondary Organic Aerosol Yields. Environ. Sci. Technol. 1996, 30, 2580-2585.

(66) Strader, R.; Lurmann, F.; Pandis, S. N. Evaluation of Secondary Organic Aerosol Formation in Winter. Atmos. Environ. 1999, 33, 4849-4863.

(67) Bowman, F. M.; Odum, J. R.; Seinfeld, J. H.; Pandis, S. N. Mathematical Model for Gas-Particle Partitioning of Secondary Organic Aerosols. Atmos. Environ. 1997, 31, 3921-3931.

(68) Gorkowski, K.; Preston, T. C.; Zuend, A. Relative-HumidityDependent Organic Aerosol Thermodynamics via an Efficient Reduced-Complexity Model. Atmos. Chem. Phys. 2019, 19, 1338313407.

(69) Gorkowski, K.; Donahue, N. M.; Sullivan, R. C. Aerosol Optical Tweezers Constrain the Morphology Evolution of Liquid-Liquid Phase-Separated Atmospheric Particles. Chem 2020, 6, 204-220.

(70) Ye, J.; Van Rooy, P.; Adam, C. H.; Jeong, C.-H.; Urch, B.; Cocker, D. R.; Evans, G. J.; Chan, A. W. H. Predicting Secondary Organic Aerosol Enhancement in the Presence of Atmospherically Relevant Organic Particles. ACS Earth Space Chem. 2018, 2, 10351046.

(71) Zuend, A.; Marcolli, C.; Peter, T.; Seinfeld, J. H. Computation of Liquid-Liquid Equilibria and Phase Stabilities: Implications for RHDependent Gas/Particle Partitioning of Organic-Inorganic Aerosols. Atmos. Chem. Phys. 2010, 10, 7795-7820.

(72) Ye, J.; Gordon, C. A.; Chan, A. W. H. Enhancement in Secondary Organic Aerosol Formation in the Presence of Preexisting Organic Particle. Environ. Sci. Technol. 2016, 50, 3572-3579.

(73) Song, C.; Zaveri, R. A.; Alexander, M. L.; Thornton, J. A.; Madronich, S.; Ortega, J. V.; Zelenyuk, A.; Yu, X.-Y.; Laskin, A.; Maughan, D. A. Effect of Hydrophobic Primary Organic Aerosols on Secondary Organic Aerosol Formation from Ozonolysis of $\alpha$-Pinene. Geophys. Res. Lett. 2007, 34, L20803.

(74) Gordon, C. A.; Ye, J.; Arthur, W. H. C. Secondary Organic Aerosol Formation Enhanced by Organic Seeds of Similar Polarity at Atmospherically Relative Humidity. STEM Fellowsh. J. 2015, 1, 6.

(75) Vaden, T. D.; Song, C.; Zaveri, R. A.; Imre, D.; Zelenyuk, A. Morphology of Mixed Primary and Secondary Organic Particles and the Adsorption of Spectator Organic Gases during Aerosol Formation. Proc. Natl. Acad. Sci. 2010, 107, 6658-6663.

(76) Robinson, E. S.; Saleh, R.; Donahue, N. M. Organic Aerosol Mixing Observed by Single-Particle Mass Spectrometry. J. Phys. Chem. A 2013, 117, 13935-13945.

(77) Robinson, E. S.; Saleh, R.; Donahue, N. M. Probing the Evaporation Dynamics of Mixed SOA/Squalane Particles Using SizeResolved Composition and Single-Particle Measurements. Environ. Sci. Technol. 2015, 49, 9724-9732.

(78) Cappa, C. D.; Wilson, K. R. Evolution of Organic Aerosol Mass Spectra upon Heating: Implications for OA Phase and Partitioning Behavior. Atmos. Chem. Phys. 2011, 11, 1895-1911.

(79) Gorkowski, K.; Donahue, N. M.; Sullivan, R. C. Emulsified and Liquid-Liquid Phase-Separated States of $\alpha$-Pinene Secondary Organic Aerosol Determined Using Aerosol Optical Tweezers. Environ. Sci. Technol. 2017, 51, 12154-12163.

(80) Wallace, J. M.; Hobbs, P. V. Atmospheric Science: An Introductory Survey; Elsevier Acad. Press: Amsterdam, 2011.

(81) Ye, Q.; Robinson, E. S.; Ding, X.; Ye, P.; Sullivan, R. C.; Donahue, N. M. Mixing of Secondary Organic Aerosols versus Relative Humidity. Proc. Natl. Acad. Sci. U.S.A. 2016, 113, 1264912654 .

(82) Ye, Q.; Upshur, M. A.; Robinson, E. S.; Geiger, F. M.; Sullivan, R. C.; Thomson, R. J.; Donahue, N. M. Following Particle-Particle Mixing in Atmospheric Secondary Organic Aerosols by Using Isotopically Labeled Terpenes. Chem 2018, 4, 318-333.

(83) Song, M.; Ham, S.; Andrews, R. J.; You, Y.; Bertram, A. K. Liquid-Liquid Phase Separation in Organic Particles Containing One and Two Organic Species: Importance of the Average O:C. Atmos. Chem. Phys. 2018, 18, 12075-12084.
(84) Seinfeld, J. H.; Erdakos, G. B.; Asher, W. E.; Pankow, J. F. Modeling the Formation of Secondary Organic Aerosol (SOA). 2. The Predicted Effects of Relative Humidity on Aerosol Formation in the $\alpha$-Pinene-, $\beta$-Pinene-, Sabinene-, $\Delta 3$-Carene-, and CyclohexeneOzone Systems. Environ. Sci. Technol. 2001, 35, 1806-1817.

(85) Cocker III, D. R.; Clegg, S. L.; Flagan, R. C.; Seinfeld, J. H. The Effect of Water on Gas-Particle Partitioning of Secondary Organic Aerosol. Part I: $\alpha$-Pinene/Ozone System. Atmos. Environ. 2001, 35, 6049-6072.

(86) Cerny, J.; Strnad, Z.; Sebor, G. Composition and Oxidation Stability of SAE 15W-40 Engine Oils. Tribol. Int. 2001, 34, 127-134.

(87) Busson-Breysse, J.; Farines, M.; Soulier, J. Jojoba Wax: Its Esters and Some of Its Minor Components. J. Am. Oil Chem. Soc. 1994, 71, 999-1002.

(88) Ng, N. L.; Canagaratna, M. R.; Jimenez, J. L.; Chhabra, P. S.; Seinfeld, J. H.; Worsnop, D. R. Changes in Organic Aerosol Composition with Aging Inferred from Aerosol Mass Spectra. Atmos. Chem. Phys. 2011, 11, 6465-6474.

(89) Russell, L. M.; Bahadur, R.; Ziemann, P. J. Identifying Organic Aerosol Sources by Comparing Functional Group Composition in Chamber and Atmospheric Particles. Proc. Natl. Acad. Sci. 2011, 108, 3516-3521.

(90) Takahama, S.; Schwartz, R. E.; Russell, L. M.; Macdonald, A. M.; Sharma, S.; Leaitch, W. R. Organic Functional Groups in Aerosol Particles from Burning and Non-Burning Forest Emissions at a HighElevation Mountain Site. Atmos. Chem. Phys. 2011, 11, 6367-6386.

(91) Liu, S.; Takahama, S.; Russell, L. M.; Gilardoni, S.; Baumgardner, D. Oxygenated Organic Functional Groups and Their Sources in Single and Submicron Organic Particles in MILAGRO 2006 Campaign. Atmos. Chem. Phys. 2009, 9, 6849-6863.

(92) Rogge, W. F.; Mazurek, M. A.; Hildemann, L. M.; Cass, G. R.; Simoneit, B. R. T. Quantification of Urban Organic Aerosols at a Molecular Level: Identification, Abundance and Seasonal Variation. Atmos. Environ., Part A 1993, 27, 1309-1330.

(93) Coury, C.; Dillner, A. M. ATR-FTIR Characterization of Organic Functional Groups and Inorganic Ions in Ambient Aerosols at a Rural Site. Atmos. Environ. 2009, 43, 940-948.

(94) Kalberer, M.; Paulsen, D.; Sax, M.; Steinbacher, M.; Dommen, J.; Prevot, A. S. H.; Fisseha, R.; Weingartner, E.; Frankevich, V.; Zenobi, R.; Baltensperger, U. Identification of Polymers as Major Components of Atmospheric Organic Aerosols. Science 2004, 303, $1659-1662$

(95) Gao, S.; Keywood, M.; Ng, N. L.; Surratt, J.; Varutbangkul, V.; Bahreini, R.; Flagan, R. C.; Seinfeld, J. H. Low-Molecular-Weight and Oligomeric Components in Secondary Organic Aerosol from the Ozonolysis of Cycloalkenes and $\alpha$-Pinene. J. Phys. Chem. A 2004, 108, 10147-10164.

(96) Tolocka, M. P.; Jang, M.; Ginter, J. M.; Cox, F. J.; Kamens, R. M.; Johnston, M. V. Formation of Oligomers in Secondary Organic Aerosol. Environ. Sci. Technol. 2004, 38, 1428-1434.

(97) Kahnt, A.; Vermeylen, R.; Iinuma, Y.; Safi Shalamzari, M.; Maenhaut, W.; Claeys, M. High-Molecular-Weight Esters in $\alpha$-Pinene Ozonolysis Secondary Organic Aerosol: Structural Characterization and Mechanistic Proposal for Their Formation from Highly Oxygenated Molecules. Atmos. Chem. Phys. 2018, 18, 8453-8467.

(98) Shilling, J. E.; Chen, Q.; King, S. M.; Rosenoern, T.; Kroll, J. H.; Worsnop, D. R.; DeCarlo, P. F.; Aiken, A. C.; Sueper, D.; Jimenez, J. L.; Martin, S. T. Loading-Dependent Elemental Composition of $\alpha$ Pinene SOA Particles. Atmos. Chem. Phys. 2009, 9, 771-782.

(99) Yu, J.; Cocker, D. R.; Griffin, R. J.; Flagan, R. C.; Seinfeld, J. H. Gas-Phase Ozone Oxidation of Monoterpenes: Gaseous and Particulate Products. J. Atmos. Chem. 1999, 34, 207-258.

(100) Song, M.; Liu, P.; Martin, S. T.; Bertram, A. K. Liquid-Liquid Phase Separation in Particles Containing Secondary Organic Material Free of Inorganic Salts. Atmos. Chem. Phys. 2017, 17, 11261-11271.

(101) Pant, A.; Parsons, M. T.; Bertram, A. K. Crystallization of Aqueous Ammonium Sulfate Particles Internally Mixed with Soot and Kaolinite: Crystallization Relative Humidities and Nucleation Rates. J. Phys. Chem. A 2006, 110, 8701-8709. 
(102) Parsons, M. T.; Mak, J.; Lipetz, S. R.; Bertram, A. K. Deliquescence of Malonic, Succinic, Glutaric, and Adipic Acid Particles. J. Geophys. Res.: Atmos. 2004, 109, D06212.

(103) Marcolli, C.; Luo, B.; Peter, T. Mixing of the Organic Aerosol Fractions: Liquids as the Thermodynamically Stable Phases. J. Phys. Chem. A 2004, 108, 2216-2224.

(104) Reid, J. P.; Bertram, A. K.; Topping, D. O.; Laskin, A.; Martin, S. T.; Petters, M. D.; Pope, F. D.; Rovelli, G. The Viscosity of Atmospherically Relevant Organic Particles. Nat. Commun. 2018, 9, 956.

(105) Koop, T.; Bookhold, J.; Shiraiwa, M.; Pöschl, U. Glass Transition and Phase State of Organic Compounds: Dependency on Molecular Properties and Implications for Secondary Organic Aerosols in the Atmosphere. Phys. Chem. Chem. Phys. 2011, 13, 19238-19255.

(106) Virtanen, A.; Joutsensaari, J.; Koop, T.; Kannosto, J.; Yli-Pirilä, P.; Leskinen, J.; Mäkelä, J. M.; Holopainen, J. K.; Pöschl, U.; Kulmala, M.; Worsnop, D. R.; Laaksonen, A. An Amorphous Solid State of Biogenic Secondary Organic Aerosol Particles. Nature 2010, 467, 824.

(107) Chan, M. N.; Chan, A. W. H.; Chhabra, P. S.; Surratt, J. D.; Seinfeld, J. H. Modeling of Secondary Organic Aerosol Yields from Laboratory Chamber Data. Atmos. Chem. Phys. 2009, 9, 5669-5680.

(108) Hansen, C. M. Hansen Solubility Parameters: A User's Handbook, 2 nd ed.; CRC Press, 2007.

(109) Reid, J. P.; Dennis-Smither, B. J.; Kwamena, N.-O. A.; Miles, R. E. H.; Hanford, K. L.; Homer, C. J. The Morphology of Aerosol Particles Consisting of Hydrophobic and Hydrophilic Phases: Hydrocarbons, Alcohols and Fatty Acids as the Hydrophobic Component. Phys. Chem. Chem. Phys. 2011, 13, 15559-15572.

(110) Cheng, Y.; Su, H.; Koop, T.; Mikhailov, E.; Pöschl, U. Size Dependence of Phase Transitions in Aerosol Nanoparticles. Nat. Commun. 2015, 6, 5923.

(111) Altaf, M. B.; Freedman, M. A. Effect of Drying Rate on Aerosol Particle Morphology. J. Phys. Chem. Lett. 2017, 8, 36133618.

(112) Kucinski, T. M.; Dawson, J. N.; Freedman, M. A. SizeDependent Liquid-Liquid Phase Separation in Atmospherically Relevant Complex Systems. J. Phys. Chem. Lett. 2019, 10, 6915-6920.

(113) Ohno, P. E.; Qin, Y.; Ye, J.; Wang, J.; Bertram, A. K.; Martin, S. T. Fluorescence Aerosol Flow Tube Spectroscopy to Detect Liquid-Liquid Phase Separation. ACS Earth Space Chem. 2021, 5, 1223-1232.

(114) Bertram, A. K.; Martin, S. T.; Hanna, S. J.; Smith, M. L.; Bodsworth, A.; Chen, Q.; Kuwata, M.; Liu, A.; You, Y.; Zorn, S. R. Predicting the Relative Humidities of Liquid-Liquid Phase Separation, Efflorescence, and Deliquescence of Mixed Particles of Ammonium Sulfate, Organic Material, and Water Using the Organic-to-Sulfate Mass Ratio of the Particle and the Oxygen-to-Carbon Elemental Ratio of the Organic Component. Atmos. Chem. Phys. 2011, 11, 1099511006. 